is the film record of the expedition that set sail from the Port of London in July, 1930, in the late Sir Ernest Shackleton's old ship the Quest, under the leadership of Gino Watkins, to explore the possibilities of an air route between England and Central Canada. It is now available under the Western Electric Company's "All-in" Hiring Service, under which films, equipment and operators can be hired under one inclusive hiring $f e e$, and is the latest addition to a series of educational films specially suitable for schools, that includes "Climbing Mount Everest" and "With Byrd at the South Pole". The photography is of a high standard, particularly in view of the trying conditions under which much of it was done. Particularly impressive was the record of a blizzard at the Expedition's base on the east coast of Greenland, views of the driving clouds of snow on the mountains being followed by others showing the subsequent gale in the fiord, which averaged 80 miles-an-hour and reached 120 miles-an-hour in gusts. Through the spindrift could be seen the floes of ice being hurried out towards the open sea, and the whole effect, combined with the accompanying sound record of the shrieking of the wind, was extremely impressive. There were glimpses also of the Eskimos and their kayaks, and of the members of the crew learning to use these vessels for the purpose of hunting seals, and finally of actual seal hunts. A good idea is given of the laborious sledge journeys in melting snow, and on ice slopes, and of the part played by the dogs-huskies from the west coast of Greenland. The educational value of the film is considerable, and it should prove very entertaining, as well as instructive, at schools.

\section{Extension of Messrs. Negretti and Zambra's Works}

Messrs. Negretti and Zambra, whose high reputation for scientific and industrial instruments is well known, have just completed a fourth extension of their works consisting mainly of a double floor building of approximately 10,500 square feet. The first floor comprises a new electrical thermometer department and experimental department with an extension for aircraft instruments. In the assembly of certain electrical thermometers it is very desirable to have a dust-free atmosphere, and very special care has been taken to ensure cleanliness in this department. For this purpose, an air-conditioning plant is installed which supplies the shop with filtered air, and if required, heated air free from dust and dirt. The air is led through a comparatively large duct along the roof and into the shop through adjustable nozzles placed at intervals along one side of the building. As the whole building is practically airtight, a series of exhaust fans are provided in the window frames on the opposite side of the shop for exhausting the air. This ensures a flow of pure air across the shop with no entry of impure air. Consideration has also been given to the flooring to avoid dust, and this is a wood block floor of Austrian oak. The test room is separated from the main shop by partitions, and this is likewise kept dust-free. The equipment of the test room includes standard potentiometer, millivoltmeters, thermometer-testing baths, etc. The expansion has resulted also in an enlargement of the existing machine shop and a further expansion for the manufacture of mercuryin-steel thermometers.

\section{Archæological Investigations in Shansi, China}

RECENT excavation and an archæological reconnaissance in the province of Shansi, China, by Mr. C. W. Bishop, associate curator of the Freer Art Gallery, Smithsonian Institution, Washington, D.C., have made possible a remarkably detailed reconstruction of the late neolithic culture of north China. In an interim summary report of the results issued by the Smithsonian Institution, it is stated that the human skeletal remains discovered indicate that in the main the prehistoric population is identical with that which occupies the country to-day. A village site, which was excavated, was found to consist of beehive-shaped pit-dwellings, about ten feet deep, which were entered from the top. The present inhabitants of the district live in dwellings excavated in the cliff face, sometimes in two or more tiers, the entrance being in front. The prehistoric villagers were settled agriculturists, with the dog and pig as their only domesticated animals. They cultivated their fields with a stone hoe. They wore woven clothes, as well as using bark-cloth, and must therefore have been acquainted with some plant affording fibre for textiles. They also wore skins and furs; and they wove baskets and mats. Their implements were of stone, bone, deer antler and, no doubt, wood. Adzes, axes and knives, both rectangular and semilunar, often perforated, were found, as well as arrow points of stone, bone and shell. Although immense quantities of potsherds were found, there were few complete vessels. It is interesting to note that the pottery falls into two classes, of which the earlier was hand-made (coiled) and the later, falling at the end of the stone age, was painted. The hand-made pottery was decorated with impressed, incised or applied ornament; the painted pottery shows a buff or red-brown ground, on which geometric designs were painted in black, red or white. There is evidence of human sacrifice, and possibly of ritual cannibalism. This culture precedes the Chinese Bronze Age, which is known to have begun some centuries before 1500 B.c.

\section{Bureau of American Ethnology}

Following the precedent of last year, the fifty. first annual report of the Bureau of American Ethnology is reduced in size and does not include the "Accompanying Papers" describing the field-work of the staff, which for so long have made this publication year by year one of the most important contributions of the United States to the literature of anthropology. The fifty-first report covers the operations of the staff of the Bureau in office and field up to June 1934. In the interests of economy, fieldwork was much curtailed, and for the most part took the form of supervision of the archæological investiga . tions which have been put in hand in the States of 